\title{
SATLOGI SANTRI PESANTREN ZAINUL HASAN GENGGONG PAJARAKAN PROBOLINGGO: LOCAL GENIUS PENGUAT KARAKTER BANGSA
}

\author{
Imam Bukhori*
}

\begin{abstract}
Culture and national character education which refer to educational of morals, values and nation character has been established since 2010. However, it movalsound is not forceful enough. By that, in 2017 government re-excavate and re-inforced the character education through nationalprogram of Reinforcement of Character Education. Educational institution becomestrategic medium because of it structures, systems and tools which has dispersed in Indonesia entirely from the outlying district to the navel. The national character education is expected carried out massively and systematically by the program that is integrated in the entire educational system, school culture, and in collaboration with community. The main values of character implemented are religius, nationalist, be autonomous, mutual assistance, and integrity. Satlogi SANTRI (the acronim of Sopan Santun, Ajeg/Istiqamah, Nasehat, Taqwallah, Ridlallah, and Ikblas Lilabi Ta'ala) six values that has been established by KH. Moh. Hasan Saifourridzall as a local genius of PesantrenZainulHasanGenggong since 1989, are basic precept, purpose and direction of behavioral rules should be hold by santri in PesantrenZainulHasanGenggong. And the six values become focus of learning, customary and cultural practice. SatlogiSANTRI as the values which contain islamism, nationalism concepts grounded on bumanism values staunch to moral principles, spiritual quotient, interpersonal dan emotional quotient in mutual accord and reinfocerd to the religius, nationalist, be autonomous, mutual assistance, and integrity values.
\end{abstract}

Keywords: satlogi SANTRI, and Karakter

* Dosen Tetap Fakultas Tarbiyah Institut Ilmu KeIslaman Zainul Hasan Genggong Kraksaan Probolinggo 


\section{PENDAHULUAN}

Pesantren sebagai institusi keagamaan mendapatkan momentum dalam sistem pendidikan nasional setelah keluarnya Undang-Undang No. 20 Tahun 2003 tentang sistem pendidikan nasional. Undang-Undang tersebut menyebutkan bahwa pendidikan keagamaan tidak hanya salah satu jenis pendidikan, tetapi sudah memiliki berbagai bentuknya seperti pendidikan diniyah, pesantren dan bentuk lain yang sejenis. ${ }^{1}$

Selanjutnya ketentuan mengenai pendidikan keagamaan dalam UU Sisdiknas tersebut diatur lebih lanjut dengan peraturan pemerintah No. 55 Tahun 2007 tentang Pendidikan Agama dan pendidikan Keagamaan. Pendidikan keagamaan berfungsi mempersiapkan peserta didik menjadi anggota masyarakat yang memahami dan mengamalkan nilai-nilai ajaran agamanya dan/atau menjadi ahli ilmu agama. Sedangkan tujuan pendidikan keagamaan adalah terbentuknya peserta didik yang memahami dan mengamalkan nilai-nilai ajaran agamanya dan/atau menjadi ahli ilmu agama yang berwawasan luas, kritis, kreatif, inovatif dan dinamis dalam rangka mencerdaskan kehidupan bangsa yang beriman, bertakwa dan berakhlak mulia. $^{2}$

Salah satu pesantren yang masih eksis menginjak usianya yang ke 180 tahun pada tahun 2019 adalah Pesantren Zainul Hasan Genggong yang berada di Desa Karangbong Kecamatan Pajarakan Kabupaten Probolinggo. Menurut sejarahnya, pesantren ini didirikan untuk mendekatkan masyarakat yang saat itu masih sangat jauh dengan nilainilai agama dan sosial. Selain itu pesantren ini didirikan atas dasar cita-cita mulia dan luhur serta tanggung jawab secara keilmuan dengan melihat fenomena masyarakat awam yang perlu mendapatkan sentuhan ilmu pengetahuan dan agama.

Perilaku masyarakat pada awal berdirinya pesantren banyak bertentangan dengan nilai-nilai agama seperti melakukan perbuatan dosa besar kepada Allah SWT, seperti perjudian, perzinahan, pembunuhan, kesyirikan dengan mensucikan dan penyembahan terhadap pohon atau tempat tertentu. Keberadaan Pesantren Genggong di tengah-tengah

${ }^{1}$ UU RI Nomor 20 Tahun 2003 Tentang Sistem Pendidikan Nasional Pasal 30 ayat (4)

${ }^{2}$ PPRI Nomor 55 Tahun 2007 Tentang Pendidikan Agama dan Pendidikan Keagamaan pasal 8 ayat (10 dan (2) 
kehidupan masyarakat yang demikian mendatangkan banyak manfaat bagi daerah sekitarnya. Lambat laun pelaksanaan dan pemahaman tentang perbuatan-perbuatan yang bertentangan dengan nilai-nilai Islam tersebut ditinggalkan. Selain itu sektor-sektor kehidupan ekonomi, sosial, dan budaya perlahan mulai terangkat dan terbenahi. Mentalitas masyarakat yang masih terpaku pada sistem adat-istiadat lama yang tidak bersesuaian dengan nilai-nilai agama perlahan diperbaiki.

Eksistensi Pesantren Zainul Hasan Genggong, sebagai sebuah lembaga pendidikan yang dibangun dan kembangkan dengan berlandaskan pandangan-pandangan filosofis tentang berbagai aspek baik agama, moralitas, ilmu pengetahuan, lingkungan dan lain sebagainya, terus berproses dalam pertumbuhan, perubahan, kesinambungan serta pembaharuan. Persoalan penting yang lazim menjadi perhatian utama dalam komunitas pesantren pada setiap waktu adalah menjaga kesinambungan pesantren dalam menjawab tantangan dan perubahan zaman.

Untuk menguatkan dasar-dasar filosofis, mengantisipasi perubahan zaman dan menguatkan jati diri Pesantren Zainul Hasan Genggong, maka KH. Moh. Hasan Saifourridzal ${ }^{3}$ merumuskan Satlogi SANTRI yang merupakan rumusan 6 akronim dari S (Sopan Santun) A (Ajeg/Istiqamah) $\mathrm{N}$ (Nasehat) T (Taqwallah) R (Ridhallah) dan I (Ikblas Lillabi Ta'ala). Nilai-nilai Satlogi SANTRI yang sampai saat ini menjadi nilai-nilai utama yang melandasi semua kebijakan dan kegiatan yang ada lembagalembaga pendidikan yang ada di bawah naungan di Pesantren Zainul Hasan Genggong. ${ }^{4}$ Nilai-nilai Satlogi SANTRI ini tentunya merupakan nilai tersendiri dan hanya ada di Pesantren Zainul Hasan Genggong yang membedakannya dengan pesantren lainnya.

Berbicara tentang santri, secara umum, tentu saja berbeda dengan peserta didik lainnya, apalagi jika dibandingkan dengan kehidupan anak

${ }^{3}$ Pengasuh ketiga dan merupakan satu-satunya putra KH. Moh. Hasan yang masih hidup yang memegang estafet kepimpinan Pesantren Zainul Hasan pada tahun 1952 sampai dengan $1991 \mathrm{M}$, dan beliau mengasuh pesantren ini selama kurang lebih 40 tahun.

${ }^{4}$ Satlogi SANTRI ini banyak terpampang di sudut-sudut pesantren dan lembaga-lembaga pendidikan yang ada di bawah naungannya. Ketika kita memasuki komplek pondok pesantren kita akan disambut dengan banner yang memajang Satlogi SANTRI didepan pintu gerbang. 
kost, atau anak asrama. Jika pondok pesantren memiliki aturan dan tata nilai tersendiri, tempat kost kebanyakan memiliki aturan yang lemah. Asal tidak merugikan tuan rumah (ibu/bapak kost), anak kost bebas melakukan semau mereka, dan biasanya tuan rumah tidak terlalu peduli bila melihat penyimpangan yang dilakukan oleh anak-anak kostnya. Dan untuk urusan kemasyarakatan anak-anak kost biasanya kurang memiliki sosialiasasi terhadap lingkungannya.

Hal ini tentu berbeda dengan pola kehidupan santri di pesantren. Meski ada diferensiasi dalam diri santri, namun masalah-masalah diferensiasi tersebut tidak sampai menimbulkan masalah-masalah yang akut, sebab setiap gejolak sosial yang timbul bisa dinetralisir atau diminimalisir oleh tradisi-tradisi pesantren. oleh karenanya meskipun berasal dari latar belakang yang bermacam-macam, santri mampu membentuk lingkungan masyarakat tersendiri yang berbeda dengan lingkungan sebelumnya. Secara sosial, dalam anggapan santri timbul rasa saling membutuhkan diantara mereka.

Nilai-nilai satlogi SANTRI, sebagaimana tersebut di atas diajarkan, baik secara ekplisit maupun implisit, ditanamkan dan dijadikan sebaga pedoman dalam menjalankan kehidupan baik di pesantren maupun di masyarakat. Penanaman dan pembiasaan nilai-nilai tersebut pada akhirnya diharapkan mampu mengantarkan santri menjadi manusia-manusia yang berjiwa satlogi SANTRI, dan menjadikan santri yang memiliki wawasan keislaman dan kebangsaan dan berkarakter berdasarkan nilainilai keislaman dan kebangsaan yang melandaskan diri pada nilai-nilai kemanusiaan. Dan santri di pesantren Zainul Hasan Genggong haruslah memegang teguh nilai-nilai satlogi SANTRI yang merupakan fondasi dalam hidup di pesantren maupun di masyarakat sebagai karakter mereka.

Jika kita menelisik, semenjak tahun 2010, kita akan menemukan bahwa Pemerintah telah mencanangkan Pendidikan Budaya dan Karakakter Bangsa yang mengacu pada pendidikan nilai, moral dan karakter bangsa. Namun, gema gerakan Pendidikan Budaya dan Karakakter Bangsa tersebutbelum cukup kuat. Oleh karenanya pendidikan karakter digaungkan dan diperkuat kembali menjadi gerakan nasional pendidikan karakter bangsa melalui program nasional Penguatan Pendidikan Karakter (PPK) pada tahun 2017.

Lembaga pendidikan menjadi sarana strategis bagi pembentukan 
karakter bangsa karena memiliki struktur, sistem dan perangkat yang tersebar di seluruh Indonesia dari daerah sampai pusat. Pembentukan karakter bangsa ini ingin dilaksanakan secara masif dan sistematis melalui program Penguatan Pendidikan Karakter (PPK) yang terintegrasi dalam keseluruhan sistem pendidikan, budaya sekolah dan dalam kerja sama dengan komunitas. Program PPK diharapkan dapat menumbuhkan semangat belajar dan membuat peserta didik senang di sekolah sebagai rumah yang ramah untuk bertumbuh dan berkembang. Tujuan program PPK adalah menanamkan nilai-nilai pembentukan karakter bangsa secara masif dan efektif melalui implementasi nilai-nilai utama Gerakan Nasional Revolusi Mental (religius, nasionalis, mandiri, gotong-royong dan integritas) yang akan menjadi fokus pembelajaran, pembiasaan, dan pembudayaan, sehingga pendidikan karakter bangsa sungguh dapat mengubah perilaku, cara berpikir dan cara bertindak seluruh bangsa Indonesia menjadi lebih baik dan berintegritas. ${ }^{5}$

Sebagaimana definisi pendidikan yang merupakan upaya yang terencana dalam proses pembimbingan dan pembelajaran bagi individu agar berkembang secara purna dan menjadi manusia yang mandiri, bertanggung jawab, kreatif, berilmu, sehat dan berakhlak (berkarakter) mulia, maka Pesantren Zainul Hasan Genggong, juga memiliki semangat yang sama dalam rangka mensukseskan tujuan pendidikan nasional. Bahkan jauh sebelum digaungkan dan diprogramkannya pendidikan karakter, pesantren ini telah memberikan sumbangsih dengan mencanangkan dan menerapkan nilai-nilai Satlogi SANTRI, untuk mencetak santri-santri dengan karakter yang unggul dalam kehidupan bermasyarakat dan bernegara.

Penelitian ini menggunakan pendekatan kualitatif. Karakteristik pokok yang menjadi perhatian dalam penelitaian kualitatif adalah kepedulian terhadap makna. Bogdan dan Taylor mengungkapkan bahwa salah penelitian kualitatif merupakan salah satu prosedur penelitian yang menghasilkan data deskriptif berupa ucapan atau tulisan dan perilaku yang diamati. ${ }^{6}$ Untuk metode penelitian yang digunakan adalah metode

5 Tim PPK Kemendikbud. 2017."Modul Pelatiban Penguatan Pendidikan Karakter.Jakarta: Kemendikbud RI. Hal. 1-2

${ }^{6}$ Lihat Soewadji, Yusuf. 2012. Pengantar Metodologi Penelitian.Jakarta: Mitra Wacana Media. Hal. 51 
antropologi kognitif dengan kerangka sebagai berikut, pertama membaca literatur yang sudah tentang masyarakat dan budaya yang ada di Pesantren Zainul Hasan Genggong. Kedua, mengumpulkan data umum berupa dokumen dan sebagainya yang dapat memberikan gambaran tentang area studi yakni Pesantren Zainul Hasan Genggong. Mengenali informan kunci yang memahami nilai-nilai Satlogi SANTRI Pesantren Zainul Hasan dengan tetap memperhatikan varian dan keterjangkauan informan. Keempat, mengasah kepekaan terhadap berbagai jenis kata, perilaku, simbol dan sebagainya untuk melakukan interpretasi terhadap nilai-nilai Satlogi SANTRI Pesantren Zainul Hasan Genggong. ${ }^{7}$ Data yang diperoleh dan dikumpulkan dari informan melalui hasil wawancara, dokumentasi dan observasi di lapangan, selanjutnya direduksi, dideskripsikan untuk kemudian dilakukan penarikan kesimpulan atau verifikasi. ${ }^{8}$

\section{PEMBAHASAN}

\section{A. Pesantren}

Menurut bahasa kata pesantren bermakna seseorang yang memperdalam pengetahuan tentang agama islam atau sering kita dengar dengan kata Santri, kemudian mendapatkan prefix pe dan an yang kemudian bermakna bunian bagi santri. Jadi tempat berkumpulnya para santri dalam satu tempat dengan jangka waktu yang cukup lama itu disebut pesantren. ${ }^{9}$ Sebagian ada yang memberikan pengertian tentang pesantren sebagai lembaga pendidikan islam dan tradisional yang hanya ada di Indonesia guna menuntut ilmu agama dan mampu menerapkan pengetahuan tersebut dalam kehidupan sehari-hari.

Sebagaimana diungkaapkan oleh Majdid, pesantren yang asal katanya adalah Santri memiliki dua pengertian, pertama berasal dari bahasa sansekerta yaitu Sastri yang berarti Melek Huruf, pengertian ini berdasarkan pada sejarah politik kekuasaan islam di Demak yang bagi mayoritas

7 Hal ini sebagaimana yang dikemukakan oleh Dede Oetomo yang dikutip oleh Syam, Nur. 2012. Mazhab-Mazhab Antropologi.Yogyakarta: LkiS. Hal. 55.

${ }^{8}$ Lihat Miles, M. Dan Huberman, A.M. 2007. Analisis Data Kualitatif. Jakarta; UI Press. Hal. 21-22

9 Asrohah, Hanun. 2004.Pelembagaan Pesantren Asal usul dan Perkembangan Pesantren Di Jawa. Jakarta: Bagian Proyek Peningkatan Informasi Penelitian dan Diklat Keagamaan. Hal. 30. 
orang Jawa Santri digolongkan pada kelas Literary, kata ini muncul karna ilmu pengetahuan yang santri dapatkan itu berasal dari kitab salaf yang menggunakan bahasa arab, kemudian dapat disimpulkan bahwa santri adalah suatu perkumpulan pemuda yang mengerti dan memahami agama. kedua, kata Santri memiliki pengertian bahwa seseorang yang senantiasa mengikuti seorang guru kemanapun guru tersebut tinggal. Dengan tujuan mereka akan mendapatkan sebuah keahlian dari gurunya, pengertian tersebut kemudian dikenal dalam istilah jawa dengan kata Cantrik.. ${ }^{10}$

Pengetian ketiga tentang Pesantren bisa diambil dari KBBI yang berarti Asrama, tempat tinggal santri untuk mengaji. Menurut istilah pesantren memiliki makna sebagai lembaga pendidikan yang memiliki tempat tinggal untuk Santri dan memberikan pengajaran tentang pengetahuan agama islam melalui kitab-kitab klasik dengan harapan mampu diterapkan dalam kehidupan sehari-hari sebagai pedoman hidup dalam bersikap dan bertindak. ${ }^{11}$

Pondok pesantren secara definitif tidak dapat diberikan batasan yang tegas melainkan terkandung fleksibilitas pengertian yang memenuhi ciri-ciri yang memberikan pengertian pondok pesantren. Jadi pondok pesantren belum ada pengertian yang lebih konkrit karena masih meliputi beberapa unsur untuk dapat mengartikan pondok pesantren secara komprehensif. Dengan demikian, sesuai dengan arus dinamika zaman, definisi serta persepsi terhadap pesantren menjadi berubah pula. Kalau pada tahap awal pesantren diberi makna dan pengertian sebagai lembaga pendidikan tradisional tetapi saat sekarang pesantren sebagai lembaga pendidikan tradisional tak lagi selamanya benar.

Kesederhanaan pesantren dahulu sangat terlihat, baik segi fisik bangunan, metode, bahan kajian dan perangkat belajar lainnya. Hal itu dilatarbelakangi kondisi masyarakat dan ekonomi yang ada pada waktu itu. Yang menjadi ciri khas dari lembaga ini adalah rasa keikhlasan yang dimiliki para santri dan sang Kyai.

Hubungan mereka tidak hanya sekedar sebagai murid dan guru, tapi lebih seperti anak dan orang tua. Tidak heran bila santri merasa kerasan

${ }^{10}$ Madjid, Nurcholish. 1994. Bilik-bilik Pesantren; Sebuab Potret Perjalanan. Jakarta: Paramadina. Hal. 19-20.

${ }^{11}$ Poerwadarmintha, WJS. 2006. Kamus Besar Bahasa Indonesia. Jakarta: Balai Pustaka. Hal. 75 
tinggal di pesantren walau dengan segala kesederhanaannya. Bentuk keikhlasan itu terlihat dengan tidak dipungutnya sejumlah bayaran tertentu dari para santri, mereka bersamasama bertani atau berdagang dan hasilnya dipergunakan untuk kebutuhan hidup mereka dan pembiayaan fisik lembaga, seperti lampu, bangku belajar, tinta, tikar dan lain sebagainya.

Materi yang dikaji adalah ilmu-ilmu agama, seperti fiqih, Nahwu, Tafsir, Tauhid, Hadist dan lain-lain. Biasanya mereka mempergunakan rujukan kitab Turost atau yang dikenal dengan kitab kuning. Di antara kajian yang ada, materi Nahwu dan Fiqih mendapat porsi Mayoritas. Hal itu karena mereka memandang bahwa ilmu Nahwu adalah ilmu kunci. Seseorang tidak dapat membaca kitab kuning bila belum menguasai Nahwu. Sedangkan materi fiqih karena dipandang sebagai ilmu yang banyak berhubungan dengan kebutuhan masyarakat (sosiologi). Tidak heran bila sebagian pakar meneybut sistem pendidikan Islam pada pesantren dahulu bersifat "fiqih orientied" atau "nahwu orientied".

Masa pendidikan tidak tertentu, yaitu sesuai dengan keinginan santri atau keputusan sang Kyai bila dipandang santri telah cukup menempuh studi padanya. Biasanya sang Kyai menganjurkan santri tersebut untuk nyantri di tempat lain atau mengamalkan ilmunya di daerah masingmasing. Para santri yang tekun biasanya diberi “ijazah” dari sang Kyai.

Pesantren sebagai institusi keagamaan mendapatkan momentum dalam sistem pendidikan nasional setelah keluarnya Undang-Undang No. 20 Tahun 2003 tentang sistem pendidikan nasional. Undang-Undang tersebut menyebutkan bahwa pendidikan keagamaan tidak hanya salah satu jenis pendidikan, tetapi sudah memiliki berbagai bentuknya seperti pendidikan diniyah, pesantren dan bentuk lain yang sejenis.

Ketentuan mengenai pendidikan keagamaan dalam UU Sisdiknas tersebut diatur lebih lanjut dengan peraturan pemerintah No. 55 Tahun 2007 tentang Pendidikan Agama dan Pendidikan Keagamaan. Pendidikan keagamaan berfungsi mempersiapkan peserta didik menjadi anggota masyarakat yang memahami dan mengamalkan nilai-nilai ajaran agamanya dan/atau menjadi ahli ilmu agama. Sedangkan tujuan pendidikan keagamaan adalah terbentuknya peserta didik yang memahami dan mengamalkan nilainilai ajaran agmanya dan/atau menjadi ahli ilmu agama yang berwawasan luas, kritis, kreatif, inovatif dan dinamis dalam rangka mencerdaskan kehidupan bangsa yang beriman, bertakwa dan berakhlak mulia. 
Pertumbuhan dan perkembangan pondok pesantren tidak terlepas hubungan dengan sejarah masuknya islam di Indonesia. Pendidikan Islam di Indonesia bermula ketika orang-orang yang masuk islam ingin mengetahui lebih banyak isi ajaran agama yang baru dipeluknya, baik mengenai tata cara beribadah, baca Al-Qur'an, dan mengetahui Islam yang lebih luas dan mendalam. Mereka ini belajar di rumah, surau, langgar, atau masjid. Di tempat inilah orang-orang yang baru masuk agama Islam dan anak-anak mereka belajar membaca Al-Qur'an dan ilmu-ilmu agama lainya, secara individual dan langsung.

Dalam perkembangannya untuk lebih memperdalam ilmu agama telah mendorong tumbuhnya pesantren yang merupakan tempat untuk melanjutkan belajar agama setelah tamat belajar dari surau, langgar atau masjid. Model pendidikan pesantren ini berkembang di seluruh Indonesia dengan nama dan corak yang sangat bervariasi. Di Jawa disebut pondok pesantren, di Aceh dikenal dengan rangka atau maunasah ${ }^{12}$, dayah di Sumatra barat dikenal surau, nama sekarang yang dikenal umum adalah pondok pesantren ${ }^{13}$.

Pesantren merupakan institusi sosial keagamaan yang menjadi wahana pendidikan bagi umat Islam yang ingin mendalami ilmu-ilmu keagamaan ${ }^{14}$. Secara umum, pesantren memiliki tipologi yang sama, yaitu sebuah lembaga yang dipimpin dan diasuh oleh kiai dalam satu komplek yang bercirikan: adanya masjid atau surau sebagai pusat pengajaran dan asrama sebagai tempat tinggal santri, di samping rumah tempat tinggal kiai, dengan "kitab kuning" sebagai buku pegangan. Di samping ciri lahiriah tersebut, masih ada ciri umum yang menandai karakteristik pesantren, yaitu kemandirian dan ketaatan santri kepada kiai yang sering disinisi sebagai pengkultusan ${ }^{15}$.

${ }^{12}$ Depatemen Agama RI. 2003. Pola Pembelajaran di Pesantren, Jakarta: Departemen Agama RI. hal. 3

${ }^{13}$ Depatemen Agama RI. 2004. Profil Pondok Pesantren Mu'adalah. Jakarta: Departemen Agama RI. hal. 1

${ }^{14}$ Mun'im, A. Rafiq Zainul. 2009. "Peran Pesantren dalam Education For All di Era Globalisasi”, http://ejournal.sunan-ampel.ac.id/index.php/JPI/ article/view/177/ 162 diakses Tanggal 24 Mei 2018.

${ }^{15}$ Bisri, Mustofa. 2007. "Pesantren dan Pendidikan", Tebuireng, Edisi 1/Tahun I/Juli-September 2007. 
Dan yang perlu digarisbawahi bahwa sejarah pesantren adalah sejarah perlawanan etnik kaum ulama dalam menentang penindasan dan diskriminasi(perbedaan warna kulit, perbedaan perlakuan terhadap sesama warga negara. Berawal ketika rencana pendidikan modern (Belanda) mulai dirancang secara menyeluruh dan diterapkan di hampir seluruh wilayah jajahan dengan menggunakan konsep stratifikasi kolonial penduduk jajahan.

Seiring dengan laju perkembangan masyarakat, maka pendidikan pesantren baik tempat, bentuk hingga substansinya telah jauh mengalami perubahan. Pesantren tidak lagi sesederhana seperti apa yang digambarkan seseorang, akan tetapi pesantren dapat mengalami perubahan sesuai dengan pertumbuhan dan perkembangan zaman.

Menurut Yacub yang dikutip oleh Khozin ${ }^{16}$ mengatakan bahwasannya ada beberapa pembagian pondok pesantren dan tipologinya yaitu:

1. Pesantren Salafi, yaitu pesantren yang tetap mempertahankan pelajarannya dengan kitab-kitab klasik dan tanpa diberikan pengetahuan umum. Model pengajarannya pun sebagaimana yang lazim diterapkan dalam pesantren salaf, yaitu dengan metode sorogan dan weton.

2. Pesantren Khalafi, yaitu pesantren yang menerapkan sistem pengajaran klasikal (madrasi), memberikan ilmu umum dan ilmu agama, serta juga memberikan pendidikan keterampilan.

3. Pesantren Kilat, yaitu pesantren yang berbentuk semacam training dalam waktu relatif singkat, dan biasanya dilaksanakan pada waktu libur sekolah. Pesantren ini menitik beratkan pada keterampilan ibdah dan kepemimpinan. Sedangkan santrinya terdiri dari siswa sekolah yang dipandang perlu mengikuti kegiatan keagamaan dipesantren kilat.

4. Pesantren terintegrasi, yaitu pesantren yang lebih menekankan pada pendidikan vocasional atau kejuruan, sebagaimana balai latihan kerja di Departemen Tenaga Kerja, dengan program yang terintegrasi. Sedangkan santrinya mayoritas berasal dari kalangan anak putus sekolah atau para pencari kerja.

${ }^{16}$ Khozin. 2006. Jejak-Jejak Pendidikan Islam di Indonesia: Rekonstruksi Sejarah Untuk Aksi. Malang: UMM Press. Hal. 101 
Sedangkan menurut Mas'ud ${ }^{17}$, ada beberapa tipologi atau model pondok pesantren yaitu:

1. Pesantren yang mempertahankan kemurnian identitas aslinya sebagai tempat menalami ilmu-ilmu agama bagi para santrinya. Semua materi yang diajarkan dipesantren ini sepenuhnya bersifat keagamaan yang bersumber dari kitab-kitab berbahasa arab (kitab kuning) yang ditulis oleh para ulama' abad pertengahan. Pesantren model ini masih banyak kita jumpai hingga sekarang, seperti pesantren Lirboyo di Kediri Jawa Timur, beberapa pesantren di daeah Sarang Kabupaten Rembang, Jawa tengah dan lain-lain.

2. Pesantren yang memasukkan materi-materi umum dalam pengajarannya, namun dengan kurikulum yang disusun sendiri menurut kebutuhan dan tidak mengikuti kurikulum yang ditetapkan pemerintah secara nasional sehingga ijazah yang dikeluarkan tidak mendapatkan pengakuan dari pemerintah sebagai ijazah formal.

3. Pesantren yang menyelenggarakan pendidikan umum di dalamnya, baik berbentuk madrasah (sekolah umum berciri khas Islam di dalam naungan Kementerian Agama) maupun sekolah (sekolah umum di bawah Dinas Pendidikan) dalam berbagai jenjangnya, bahkan ada yang sampai Perguruan Tinggi yang tidak hanya meliputi fakultasfakultas keagamaan meliankan juga fakultas-fakultas umum. Pesantren Tebu Ireng di Jombang Jawa Timur adalah contohnya.

4. Pesantren yang merupakan asrama pelajar Islam dimana para santrinya belajar disekolah-sekolah atau perguruan-perguruan tinggi diluarnya. Pendidikan agama dipesantren model ini diberikan diluar jam-jam sekolah sehingga bisa diikuti oleh semua santrinya. Diperkirakan pesantren model inilah yang terbanyak jumlahnya.

Perkembangan akhir-akhir ini menunjukkan bahwa beberapa pesantren ada yang tetap berjalan meneruskan segala tradisi yang diwarisi secara turun temurun tanpa perubahan dan improvisasi yang berarti kecuali sekedar bertahan. Namun ada juga pesantren yang mencoba mencari jalan sendiri dengan harapan mendapatkan hasil yang lebih baik

${ }^{17}$ Mas'ud, Abdurrahman. 2007. Memahami Agama Damai Dunia Pesantren, dalam Badrus Sholeh (ed.). Budaya Damai Komunitas Pesantren. Jakarta: LP3ES. Hal. $149-150$ 
dalam waktu yang singkat. Pesantren semacam ini adalah pesantren yang menyusun kurikulum berdasarkan pemikiran akan kebutuhan santri dan masyarakat sekitarnya.

Maka apapun motif perbincangan seputar dinamika pesantren memang harus diakui mempunyai dampak yang besar, misalnya dengan kemajuan zaman pesantren semakin dituntut dengan munculnya teknologi yang canggih, sehingga pesantren-pun tidak ketinggalan zaman untuk selalu mengimbangi dari setiap persoalan-persoalan yang terkait dengan pendidikan maupun sistem di dalam pendidikan itu sendiri, mulai dari sisi mengaji ke mengkaji. Itupun merupakan sebuah bukti konkrit di dalam pesantren, bahwa sebenarnya pesantren telah mengalami perkembangan dan pertumbuhan yang cukup signifikan. Karena pesantren tak akan pernah mengalami statis selama dari tiap unsur-unsur pesantren tersebut bisa menyikapi dan merespon secara baik hal-hal yang paling aktual di dalam lingkungan masyarakat.

\section{B. Penguatan Pendidikan Karakter}

Secara etimologis, karakter diartikan dengan tabiat, sifat-sifat kejiwaan, akhlak atau budi pekerti yang membedakan seseorang dengan yang lain, dan watak. Karakter juga bisa berarti huruf, angka, ruang, simbol khusus yang dapat dimunculkan pada layar dengan papan ketik. ${ }^{18}$ Lebih lanjut karakter juga diartikan sebagai watak, tabiat, akhlak atau kepribadian seseorang yang terbentuk dari hasil internalisasi berbagai kebajikan yang diyakini dan digunakan sebagai landasan untuk cara pandang, berpikir, bersikap dan bertindak. ${ }^{19}$ Selain itu karakter juga dimaknai sebagai nilainilai yang unik-baik yang terpeteri dalam diri dan terejawantahkan dalam perilaku dan merupakan pancaran dari olah pikir, olah hati, olah rasa dan karsa, serta olahraga seseorang atau sekelompok orang. ${ }^{20}$

Lebih lanjut pendidikan karakter diartikan sebagai upaya penanaman kecerdasan dalam berfikir, penghayatan dalam bentuk sikap,

${ }^{18}$ Tim Penyusun Kamus Bahasa Indonesia. 2008.Kamus Bahasa Indonesia. Jakarta: Pusat Bahasa Depdiknas. Hal. 682.

${ }^{19}$ Kemendiknas. 2011.Bahan Pelatiban Pengembangan Pendidikan Budaya dan Karakter Bangsa. Jakarta: Dirjen Pendas.Hal. 3

${ }^{20}$ Kemendiknas. 2010. Desain Induk Pendidikan Karakter. Jakarta: Dirjen Pendas. Hal. 7. 
dan pengamalan dalam bentuk perilaku yang sesuai dengan nilai-nilai luhur yang menjadi jati dirinya, diwujudkan dalam interaksi dengan Tuhannya, diri sendiri, masyarakat dan lingkungannya. ${ }^{21}$

Karakter juga diidentikkandengan kepribadian atau akhlak yang merupakan nilai-nilai perilaku manusia yang universal yang meliputi seluruh aktivitas manusia, baik dalam rangka berhubungan dengan Tuhannya, dengan dirinya, dengan sesam manusia, maupun dengan lingkungannya, yang terwujud dalam pikiran, sikap, perasaan, perkataan, dan perbuatan berdasarkan norma-norma agama, hukum, tata krama, budaya, adat istiadat dan atau bersumber dari bentukan-bentukan yang diterima dari lingkungan, misalnya keluarga pada masa kecil dan juga bawaan sejak lahir. ${ }^{22}$

Dalam Al-Qur'an makna akhlak sebagaimana tersirat dalam firman Allah Surat al-Qalam ayat 4 yang berbunyi “dan sesunggubnya kamu benarbenar berbudi pekerti yang agung" 23 , menunjukkan bahwa Nabi Muhammad adalah manusia yang memiliki akhlak yang mulia dan agung. Ayat tersebut merupakan bantahan terhadap orang-orang kafir yang telah menuduh Rasulullah adalah gila atau sesat karena telah mengajarkan kebenaran melalui ayat-ayat Allah yang diturunkan kepadanya.

Secara umum karakter dalam perspektf Islam dibagi menjadi dua, yakni karakter mulia (al-akblaq al-mabmudah) dan karakter tercela (alakblaq al-madzmumah). Karakter mulia adalah karakter yang harus di aplikasikan, dilaksanakan, diterapkan dan diejawantahkan dalam hidup keseharian setiap muslim. Sedangkan karakter tercela adalah karakter yang harus dijauhi, ditinggalkan dan dibuang jauh-jauh dari diri seorang muslim. Hal ini sebagaimana tersirat dalam Surat al-Nahl ayat 90 yang berbunyi "Sesungguhnya Allab menyuruh (kamu) Berlaku adil dan berbuat kebajikan, memberi kepada kaum kerabat, dan Allab melarang dari perbuatan keji, kemungkaran dan permusuban. Dia memberi pengajaran kepadamu agar kamu dapat mengambil pelajaran". ${ }^{24}$

${ }^{21}$ Zubaedi. 2011. Desain Pendidikan Karakter: Konsepsi dan Aplikasinya dalam Lembaga Pendidikan. Jakarta: Kencana. Hal. 17.

${ }^{22}$ Koesoema, Doni. 2010. Pendidikan Karakter: Strategi Mendidik Anak Di Zaman Global. Jakarta: Grasindo. Hal. 80.

${ }^{23}$ Departemen Agama RI. 2012.Al-Quran dan Terjemabnya. Jakarta: Departemen Agama RI. Hal. 828

${ }^{24}$ Departemen Agama RI. 2012. Al-Quran dan Terjemahnya. Jakarta: Departemen Agama RI. Hal 434 
Karakter pada diri seseorang tidak bisa secara otomatis muncul dan terejawantah begitu saja. Karakter pada diri seseorang akan berkembang secara maksimal hanya melalui proses pengubahan sikap dan tata laku melalui pembelajaran, pelatihan dan pembiasaan. Oleh karena itu karakter haruslah dilembagakan melalui pendidikan yang selanjutnya disebut dengan pendidikan karakter. Pendidikan karakter menanamkan kebiasan tentang kebiasaan yang baik sehingga peserta didik menjadi paham (domain kognitif), tentang mana yang baik, benar dan mana yang salah, serta mampu merasakan (domain afektif), tentang nilai yang baik dan biasa melakukan (domain perilaku). ${ }^{25}$

Dalam penguatan pendidikan karakter, lingkungan sosial dan budaya bangsa yang harus dijadikan patokan adalah Pancasila, yang menjunjung tinggi nilai ketuhanan, kemanusiaan, keadilan, persatuan, demokrasi dan kesetiakawanan sosial, jadi pendidikan budaya dan karakter adalah mengembangkan nilai-nilai Pancasila pada diri peseta didik melalui pendidikan hati, otak, dan fisik. Pendidikan kearah terbentuknya karakter bangsa para siswa merupakan tanggung jawab semua pemangku kepentingan pendidikan, bukan hanya guru. Oleh karena itu, pembinaannya pun harus terus dilakukan oleh semua komponen masyarakat. Dengan demikian, kurang tepat jika dikatakan bahwa mendidik para siswa agar memiliki karakter bangsa hanya ditimpahkan pada guru, orang tua atau organisasi tertentu. ${ }^{26}$

Pembentukan karakter merupakan sesuatu yang sangat penting tetapi tidak mudah dilakukan, karena perlu dilakukan dalam proses yang lama dan berlangsung seumur hidup. Apalagi karakter itu tidak langsung dimiliki oleh anak sejak ia lahir akan tetapi karakter diperoleh melalui berbagai macam pengalaman di dalam hidupnya. Pembentukan karakter merupakan suatu usaha yang melibatkan semua pihak, baik orang tua, sekolah, lingkungan sekolah, dan masyarakat luas. Oleh karena itu, pembentukan karakter tidak akan berhasil apabila semua lingkungan pendidikan tidak ada kesinambungan, kerjasama dan keharmonisan. Pembentukan karakter merupakan bagian penting dalam proses

${ }^{25}$ Kemendiknas. 2010. Kerangka Acuan Pendidikan Karakter. Jakarta: Dirjen PT. Hal. 10-11.

${ }^{26}$ Tim PPK Kemendikbud. 2017.Penguatan Pendidikan Karakter. Jakarta: Kemendikbud. Hal. 9 
pendidikan dalam keluarga. Pada umumnya setiap orang tua berharap anaknya berkompeten dibidangnya dan berkarakter baik.

Pendidikan karakter, sekali lagi, mengajarkan kebiasaan cara berpikir dan berperilaku yang membantu individu untuk hidup dan bekerja bersama sebagai keluarga, masyarakat dan warga negara serta membantu mereka untuk membuat keputusan yang dapat dipertanggungjawabkan. Sebagai pendidikan nilai, pendidikan moral, pendidikan budi pekerti, pendidikan watak, yang bertujuan untuk mengembagkan kemampuan peserta didik dalam memberikan keputusan baik-buruk, memelihara apa yang baik, dan mewujudkan kebaikan dalam kehidupan sehari-hari dengan sepenuh hati, memiliki keteraturan dalam setiap tindakan maka keberhasilan pendidikan karakter diukur berdasarkan hirarki nilai.Nilai menjadi pedoman normatif dalam setiap tindakan. Keterpadauan dan ketersambungan nilai memberikan keberanian dan membuat sesorang mampu dengan teguh memegang prinsip. Otonomi seseorang dalam menginternalisasikan nilai-nilai akan menghasilkan kesetiaan, komitmen dan penghormatan atas pilihan-pilihan itu sendiri.

Adapun nilai-nilai yang dikembangkan dalam pendidikan budaya dan karakter bangsa diidentifikasi dari sumber-sumber berikut ini. ${ }^{27}$

1. Agama

Masyarakat Indonesia adalah masyarakat beragama. Oleh karena itu, kehidupan individu, masyarakat, dan bangsa selalu didasari pada ajaran agama dan kepercayaannya. Secara politis, kehidupan kenegaraan pun didasari pada nilai-nilai yang berasal dari agama. Atas dasar pertimbangan itu, maka nilai-nilai pendidikan budaya dan karakter bangsa harus didasarkan pada nilai-nilai dan kaidah yang berasal dari agama.

2. Pancasila

Negara kesatuan Republik Indonesia ditegakkan atas prinsipprinsip kehidupan kebangsaan dan kenegaraan yang disebut Pancasila. Pancasila terdapat pada Pembukaan UUD 1945 dan dijabarkan lebih lanjut dalam pasal-pasal yang terdapat dalam UUD 1945. Artinya, nilai-nilai yang terkandung dalam Pancasila menjadi nilai-nilai yang mengatur kehidupan politik, hukum, ekonomi, kemasyarakatan,

${ }^{27}$ Kemendiknas. 2011. Bahan Pelatihan Pengembangan Pendidikan Budaya dan Karakter Bangsa. Jakarta: Dirjen Pendas. Hal. 9-10 
budaya, dan seni. Pendidikan budaya dan karakter bangsa bertujuan mempersiapkan peserta didik menjadi warga negara yang lebih baik, yaitu warga negara yang memiliki kemampuan, kemauan, dan menerapkan nilai-nilai Pancasila dalam kehidupannya sebagai warga negara.

3. Budaya

Sebagai suatu kebenaran bahwa tidak ada manusia yang hidup bermasyarakat yang tidak didasari oleh nilai-nilai budaya yang diakui masyarakat itu. Nilai-nilai budaya itu dijadikan dasar dalam pemberian makna terhadap suatu konsep dan arti dalam komunikasi antaranggota masyarakat itu. Posisi budaya yang demikian penting dalam kehidupan masyarakat mengharuskan budaya menjadi sumber nilai dalam pendidikan budaya dan karakter bangsa.

4. Tujuan Pendidikan Nasional

Sebagai rumusan kualitas yang harus dimiliki setiap warga negara Indonesia, dikembangkan oleh berbagai satuan pendidikan di berbagai jenjang dan jalur. Tujuan pendidikan nasional memuat berbagai nilai kemanusiaan yang harus dimiliki warga negara Indonesia. Oleh karena itu, tujuan pendidikan nasional adalah sumber yangpaling operasional dalam pengembangan pendidikan budaya dan karakter bangsa.

Berdasarkan sumber-sumber tersebut, maka gerakan Penguatan Pendidikan Karakter (PPK), yang merupakan kelanjutan dan kesinambungan dari Gerakan Nasional Pendidikan Karakter Bangsa Tahun 2010 dan merupakan bagian integral Nawacita yang dicanangkan sejak tahun 2014 menekankan lima nilai utama karakter yang saling berkaitan membentuk jejaring nilai yang perlu dikembangkan sebagai prioritas Gerakan PPK. Kelima nilai utama karakter bangsa yang dimaksud adalah sebagai berikut: ${ }^{28}$

1. Religius

Nilai karakter religius mencerminkan keberimanan terhadap Tuhan yang Maha Esa yang diwujudkan dalam perilaku melaksanakan ajaran agama dan kepercayaan yang dianut, menghargai perbedaan agama,

${ }^{28}$ Tim PPK Kemendikbud. 2017Penguatan Pendidikan Karakter. Jakarta: Kemendikbud. Hal. 13 
menjunjung tinggi sikap toleran terhadap pelaksanaan ibadah agama dan kepercayaan lain, hidup rukun dan damai dengan pemeluk agama lain.

Nilai karakter religius ini meliputi tiga dimensi relasi sekaligus, yaitu hubungan individu dengan Tuhan, individu dengan sesama, dan individu dengan alam semesta (lingkungan). Nilai karakter religius ini ditunjukkan dalam perilaku mencintai dan menjaga keutuhan ciptaan.

Subnilai religius antara lain cinta damai, toleransi, menghargai perbedaan agama dan kepercayaan, teguh pendirian, percaya diri, kerja sama antar pemeluk agama dan kepercayaan, antibuli dan kekerasan, persahabatan, ketulusan, tidak memaksakan kehendak, mencintai lingkungan, melindungi yang kecil dan tersisih.

2. Nasionalis

Nilai karakter nasionalis merupakan cara berpikir, bersikap, dan berbuat yang menunjukkan kesetiaan, kepedulian, dan penghargaan yang tinggi terhadap bahasa, lingkungan fisik, sosial, budaya, ekonomi, dan politik bangsa, menempatkan kepentingan bangsa dan negara di atas kepentingan diri dan kelompoknya.

Subnilai nasionalis antara lain apresiasi budaya bangsa sendiri, menjaga kekayaan budaya bangsa,rela berkorban, unggul, dan berprestasi, cinta tanah air, menjaga lingkungan,taat hukum, disiplin, menghormati keragaman budaya, suku,dan agama.

3. Mandiri

Nilai karakter mandiri merupakan sikap dan perilaku tidak bergantung pada orang lain dan mempergunakan segala tenaga, pikiran, waktu untuk merealisasikan harapan, mimpi dan cita-cita.

Subnilai mandiri antara lain etos kerja (kerja keras), tangguh tahan banting, daya juang, profesional, kreatif, keberanian, dan menjadi pembelajar sepanjang hayat.

4. Gotong Royong

Nilai karakter gotong royong mencerminkan tindakan menghargai semangat kerja sama dan bahu membahu menyelesaikan persoalan bersama, menjalin komunikasi dan persahabatan, memberi bantuan/ pertolongan pada orang-orang yang membutuhkan.

Subnilai gotong royong antara lain menghargai, kerja sama, 
inklusif, komitmen atas keputusan bersama, musyawarah mufakat, tolongmenolong, solidaritas, empati, anti diskriminasi, anti kekerasan, dan sikap kerelawanan.

5. Integritas

Nilai karakter integritas merupakan nilai yang mendasari perilaku yang didasarkan pada upaya menjadikan dirinya sebagai orang yang selalu dapat dipercaya dalam perkataan, tindakan, dan pekerjaan, memiliki komitmen dan kesetiaan pada nilai-nilai kemanusiaan dan moral (integritas moral).

Karakter integritas meliputi sikap tanggung jawab sebagai warga negara, aktif terlibat dalam kehidupan sosial, melalui konsistensi tindakan dan perkataan yang berdasarkan kebenaran.

Subnilai integritas antara lain kejujuran, cinta pada kebenaran, setia, komitmen moral, anti korupsi, keadilan, tanggungjawab, keteladanan, dan menghargai martabat individu (terutama penyandang disabilitas).

Kelima nilai utama karakter bukanlah nilai yang berdiri dan berkembang sendiri-sendiri melainkan nilai yang berinteraksi satu sama lain, yang berkembang secara dinamis dan membentuk keutuhan pribadi. Dari nilai utama manapun pendidikan karakter dimulai, individu dan sekolah pertlu mengembangkan nilai-nilai utama lainnya baik secara kontekstual maupun universal. Nilai religius sebagai cerminan dari iman dan takwa kepada Tuhan Yang Maha Esa diwujudkan secara utuh dalam bentuk ibadah sesuai dengan agama dan keyakinan masing-masing dan dalam bentuk kehidupan antarmanusia sebagai kelompok, masyarakat, maupun bangsa. Dalam kehidupan sebagai masyarakat dan bangsa nilainilai religius dimaksud melandasi dan melebur di dalam nilai-nilai utama nasionalisme, kemandirian, gotong royong, dan integritas. Demikian pula jika nilai utama nasionalis dipakai sebagai titik awal penanaman nilai-nilai karakter, nilai ini harus dikembangkan berdasarkan nilai-nilai keimanan dan ketakwaan yang tumbuh bersama nilai-nilai lainnya.

Jadi pada dasarnya pendidikan karakter adalah upaya penanaman nilainilai yang khas yang baik yang terpatri dalam diri dan terejawantahkan dalam perilaku yang meliputi serangkaian sikap seperti keinginan untuk melakukan hal yang terbaik dalam mempertahankan prinsip-prinsip moral dan kecakapan interpersonal dan emosional yang memungkinkan 
seseorang berinteraksi secara efektif dalam berbagai keadaan serta komitmen untuk berkontribusi dengan komunitas dan masyarakatnya.

\section{Satlogi SANTRI: Local Genius Pesantren Zainul Hasan Genggong}

Pondok Pesantren Zainul Hasan atau yang lebih dikenal dengan nama Pondok Genggong, yang beralamat di Desa Karangbong Kecamatan Pajarakan Kabupaten Probolinggo, merupakan salah satu pesantren yang sudah ada sejak tahun $1259 \mathrm{H}$ atau $1839^{29}$. Berdasarkan sejarah pesantren, sampai saat ini, Pesantren Genggong telah diasuh oleh empat orang pengasuh. Pengasuh pertama sekaligus pendirinya adalah KH. Zainul Abidin. Beliau menjadi mengasuh pesantren sejak didirikan hingga wafat pada 1890 M. Pengasuh kedua adalah KH. Mohammad Hasan. Beliau adalah menantu KH. Zainul Abidin dari putri beliau yang bernama Nyai Ruwaidah. Sejak pernikahan inilah KH. Mohammad Hasan membantu mertuanya dalam membina pesantren. Beliau mengembangkan sistem pendidikan pesantren salafiyah (tradisional) dengan metode pembelajaran dan pendidikan klasikal. Perkembangan Pondok Genggong makin lama makin berkembang dan jumlah santri makin banyak berdatangan dari luar daerah. Beliau wafat pada tahun 1955 M. Namun kepemimpinan pesantren telah diserahkan pada tahun 1952 M. di saat KH. Mohammad Hasan sudah berusia senja kepada KH. Hasan Saifourridzal. Pada masa beliaulah pengembangan pendidikan formal mulai dilakukan dengan memadukan kurikulum pendidikan agama dan salafiyah dengan kurikulum nasional yang ditandai dengan membuka lembaga pendidikan dari tingkat pendidikan dasar hingga pendidikan tinggi. Beliau menjadi pengasuh pesantren tahun sejak tahun 1952 hingga wafat pada 1991 M. ${ }^{30}$

${ }^{29}$ Sampai saat ini tidak ditemukan data yang pasti terkait dengan tanggal dan bulan yang valid terkait dengan berdirinya pesantren Zainul Hasan Genggong, hanya saja pada tanggal 1 Muharram $1379 \mathrm{H}$. atau bertepatan dengan 19 Juli 1959 M. KH. Moh. Hasan Saifourrdzall menetapkan nama Pesantren Zainul Hasan Genggong yang semula bernama Asrama Pelajar Islam Genggong, hal ini dimaksudkan untuk tabarraukan mengabadikan kedua pendiri yakni Syaikh Zainul Abidin dan KH. Moh. Hasan

${ }^{30}$ Lihat Aziz, Abd. 2013. Filsafat Pesantren Genggong. Probolinggo: STAI Zainul Hasan Genggong. Hal. 14-20 
Pesantren Zainul Hasan Genggong sendiri, secara kultur merupakan sebuah pesantren yang berada pada kultur pendalungan, yakni proses kultural yang terjadi di wilayah Tapal Kuda, ${ }^{31}$ sebagai generasi baru hasil perkawinan campuran Madura-Jawa dan percampuran budaya MaduraJawa yang melahirkan masyarakat berbudaya baru yang terbentuk dari percampuran dua budaya dominan, Jawa dan Madura, sehingga bahasa, adat-istiadat, dan keseniannya pun berbeda. ${ }^{32}$

Pada hakikatnya, setiap pesantren termasuk pesantren Zainul Hasan Genggong, sebagaimana menurut Abdurrahman Wahid, ${ }^{33}$ adalah sebuah unit sub-kultur. Dan setiap unit sub-kultur memiliki nilai-nilai yang senantiasa diwariskan, ditafsirkan, dan dilaksanakan seiring dengan proses perubahan sosial yang terjadi di masyarakat. Adapun nilai-nilai Pesantren Zainul Hasan Genggong terakumulasi dalam prinsip yang disebut "Satlogi SANTRI" yang digagas oleh KH. Hasan Saifouridzall ${ }^{34}$ merupakan nilai-nilai kearifan lokal (local genius)dan merupakanakronim dari kata santri itu sendiri yakni S (Sopan Santun) A (Ajeg/Istiqomah) N (Nasehat) T (Taqwallah) R (Ridlallah) I (Ikhlas Lillahi Ta'ala). Konstruksi nilai tersebut dirumuskan sebagai karakteristik santri dan alumni Pesantren Zainul Hasan Genggong, dandiyakini sebagai kekuatan yang mampu membangun dan membentuk karakter, integritas dan keteladanan luar biasa dalam kehidupan bermasyarakat berbangsa dan bernegara.

${ }^{31}$ Istilah Tapal Kuda ini juga masih bisa diperdebatkan, tapi secara umum diartikan sebagai bagian Timur Jawa, yakni Pasuruan, Probolinggo, Lumajang, Jember, Bondowoso, Situbondo, dan Banyuwangi, sebuah wilayah geokultural yang ditempati masyarakat Madura yang bermigrasi dari tanah leluhurnya, juga sebagian masyarakat Jawa Kulonan.

${ }^{32}$ Mengenai hal ini bisa dilihat dalam Kusnadi. 2001. "Masyarakat "Tapal Kuda": Konstruksi Kebudayaan dan Kekerasan Politik", dalam Jurnal Ilmu-ilmu Humaniora, Vol.III, No.2

${ }^{33}$ Lihat Abdurrahman Wahid, Menggerakkan Tradisi, (Yogyakarta: LkiS, 2010). Hal. 1

${ }^{34}$ Mengenai tepatnya kapan satlogi SANTRI ini dicetuskan masih belum ditemukan data yang jelas, tetapi jika ditelusuri, maka satlogi santri ini terkodifikasi sejak tahun 1989 dan bisa dilihat dalam Umar, Arief dkk. 1989. Pesantren Zainul Hasan Genggong Kraksaan, Sejarah Perjalanan dan Perkembangannya: 150 Tabun Menebar Ilmu di Jalan Allah. Probolinggo: TP. Hal. 257-267. Juga bisa dilihat dalam Aziz, Abd. 2013. Filsafat Pesantren Genggong. Probolinggo: STAI Zainul Hasan Genggong. Hal. 202 
Interpretasi dari nilai-nilai tersebut adalah pertama, Sopan Santun, adalah landasan bimbingan seorang untuk dapat berinteraksi dengan Allah dan sistem sosialnya dengan mengedepankan keluhuran pekerti dalam bertindak sebagai sumber kekuatan, konsep ini dirumuskan untuk kemapanan dan kejayaan pesantren dan membangun etika santri dengan nilai-nilai etis spritual. Dasar dari nilai ini adalah sabda Rasulullah SAW. "Dan bergaullah dengan manusia dengan pergaulan yang baik". ${ }^{35}$ Sopansantun merupakan unsur penting dalam kehidupan sosial keseharian, karena dengan menunjukkan kesopan santunan inilah sesorang dapat dihargai dan disenangi keberadaannya sebagai makhluk sosial di manapun ia berada. ${ }^{36}$ Sopan santun juga diartikan sebagai peraturan hidup yang timbul dari hasil pergaulan dalam masyarakat dan juga dianggap sebagai tuntutan yang harus dijalankan dalam pergaulan sehari-hari dalam masyarakat. Beberapa contoh perilaku yang mencerminkan sopan santun misalnya; menghormati yang lebih tua, menyayangi yang lebih muda, menjaga diri dengan perilaku terpuji, menaati peraturan dan berperan aktif dalam kegiatan-kegiatan yang sudah dijadwalkan.

Lebih lanjut sopan juga diartikan sebagai sikap hormat dan beradab dalam berperilaku, santun dalam bertutur kata, budi bahasa dan kelakuan yang baik sesuai dengan adat istidat dan budaya yang ada di masyarakat. Perilaku sopan mencerminkan perilaku diri sendiri, karena sopan memiliki arti hormat, ta'dzim, dan tertib menurut adat istiadat. Sedangkan santun diartikan sebagai sifat yang halus dan baik hati dari sudut pandang bahasa maupun tata perilakunya kepada semua orang. ${ }^{37}$ Jadi sopan santun

${ }^{35}$ HR. Imam Ahmad, Imam Trumdzi dan Imam Hakim dari Abi Dzarr, dan Riwayat Imam Ahmad dan Imam Turmudzi dari Mu'adz sebagaimana dikutip olehUmar, Arief dkk. 1989. Pesantren Zainul Hasan Genggong Kraksaan, Sejarah Perjalanan dan Perkembangannya: 150 Tabun Menebar Ilmu di Jalan Allah, Probolinggo: TP. Hal. 257.

${ }^{36}$ Wawancara dengan KH. Moh. Hassan Malik (Gus Alex, cucu KH. Moh. Hasan Saifourridzall) di kantor MA. Zainul Hasan 1 Komplek Gedung P5 Pesantren Zainul Hasan Genggong pada tanggal 11 Agustus 2019. Hal yang senada juga disampaikan oleh KH. Ahmad Fauzi Imran, pengasuh PP. Islamiyah Syafi'iyah Kotaanyar yang merupakan santri KH. Moh. Hasan Saifourdzall pada tanggal 23 Agustus 2019.

${ }^{37}$ Wawancara dengan KH. Moh. Ahsan Qamaruz Zaman (Gus Aka, cucu KH. Moh. Hasan Saifourridzall) di kantor pusat Pesantren Zainul Hasan Pesantren Zainul Hasan Genggong pada tanggal 17 Agustus 2019. Hal yang senada juga 
meruoakan sifat lemah lembut yang diiliki oleh setiap orang yang dapat dilihat dari sudut pandang bahasa maupun perilaku dalam kehidupan sehari-hari yang menjunjung tinggi nilai-nilai menghormati, menghargai, dan berakhlak mulia.

Dan tentu saja nilai-nilai sopan santun merupakan pengejawantahan dari ajaran-ajaran Islam sebagaimana yang diajarkan oleh Rasulullah SAW yang mengatakan "Lima hal yang jika tidak ada dalam diri seseorang maka ia tidak akan memiliki penganut; agama, rasa malu, budi pekerti dan kesopanan. ${ }^{38}$ Dan jika kita mencermati ayat-ayat Al-Qur'an, dapat kita pahami bahwa Allah SWT Yang Maha dalam segalanya, ketika berbicara dengan hambanya tetap menjaga sopan santun. ${ }^{39} \mathrm{Hal}$ ini pulalah yang diejawantahkan oleh KH. Moh. Hasan Saifourridzall. Kepada siapapun beliau bersikap sontan dan senantiasan menggunakan bahasa yang santun (madura halus) bahkan kepada anak kecil. ${ }^{40}$

Kedua, Ajeg (istiqomab), berarti jalan lurus, teguh atau konsisten dengan sikap batin yang kokoh tak tergoyahkan berdasarkan nilainilai kebenaran dan cita-cita walaupun harus menghadapi berbagai macam kesulitan, rintangan, cobaan dan ujian.Sikap ajeg (istiqomah) yang dimiliki santri dapat mengantarkan keberhasilan dalam hidupnya. Nilai ini didasarkan pada firman Allah SWT "Dan sekiranya mereka tetap berjalan lurus di atas jalan itu (agama Islam), benar-benar Kami akan memberi minum kepada mereka air yang segar (rezeki yang banyak)." Dan juga sabda Rasulullah SAW."Katakanlah wahai Muhammad! Aku Beriman kepada Allah, kemudian istiqmablah! ${ }^{41}$

disampaikan oleh KH. Ahmad Fauzi Imran, pengasuh PP. Islamiyah Syafi'iyah Kotaanyar yang merupakan santri KH. Moh. Hasan Saifourdzall pada tanggal 03 September 2019.

${ }^{38}$ Lihat Biharul Anwar, Juz 75. Hlm. 67

${ }^{39} \mathrm{Hal}$ ini bisa dilihat dalam Surat Al- Nur: 63 dan juga Surat Al-Baqarah: 83

${ }^{40}$ Sebagaimana dituturkan oleh KH. Moh. Hasan Saiful Islam (Putra KH. Moh. Hasan Saifourridzall) ketika menceritakan manaqib KH. Moh. Hasan dalam acara haul di Pesantren Zainul Hasan Genggong pada 15 Juni 2019 M. atau 10 Syawal $1440 \mathrm{H}$.

${ }^{41}$ Lihat Surat Al-Jinn: 16 dan HR. Sufyan dari Abdillah Al-Tsaqafy dan Ahmad dan sanadnya bersambung kepada Imam Muslim, Imam Turmuzi, Imam Nasa'i dan Ibnu Majah sebagaimana dikutipoleh Umar,Arief dkk. 1989. Pesantren Zainul Hasan Genggong Kraksaan, Sejarah Perjalanan dan Perkembangannya: 150 Tabun Menebar Ilmu di Jalan Allah. Probolinggo: TP, Hal. 259. 
Dalam ayat tersebut diterangkan bahwa siapa saja diantara manusia atau jin yang tetap berpegang dan menjalankan ketentuan-ketentuan Islam, Allah akan melapangkan rezekinya serta memudahkan semua urusan dunia mereka dan mendapatkan balasan nikmat yang sempurna. Secara implisit dikemukakan bahwa siapa saja, tidak memandang latar belakang, latar belakang sosial dan latar belakang geneologis, akan mendapatkan kemudahan, kehormatan dan kemulian dihadapan Allah SWT. dan dihadapan manusia dengan cara ajeg (istiqamah) dalam memegang teguh dan menjalankan ajaran-ajaran Islam. Ajeg (istiqamah) memang mudah diucapkan, tetapi dalam prakteknya menjadi lebih sulit dan perlu usaha keras dan ketetapan hati. Ajeg adalah perbuatan dan perilaku yang harus terkait antara lisan, hati dan jiwa. Seorang santri haruslah mampu menjaga lisan, hati dan jiwanya tetap berada dalam keimanan dan taat kepada Allah SWT. dan berada di jalan yang lurus menuju Allah SWT. ${ }^{42}$ Oleh karenanya santri semenjak masuk di pesantren harus dan dianjurkan kepada santri menjaga keajegan dalam beberapa hal dan kegiatan misalnya sholat fardhu berjamaah, mengaji dan tadarrus Al-Qur'an ba'da subuh dan ba'da maghrib, bertutur kata santun kepada semua orang dan lain sebagainya.

Lebih lanjut dikatakan bahwa keajegan (keistiqamahan) dalam iman berarti bersungguh-sungguh menjaga lisan, hati dan perilaku dengan senantiasa berada di jalan Allah dengan menjalankan semua perintah dan menjauhi larangan-larangannya. Bagi mereka yang ajeg, maka tidak akan terdapat sedikitpun rasa takut, rasa susah, dan dalam diri mereka hanya akan ada rasa selalu bergantung kepada Allah. Dan ada akhirnya kehormatan dan kemulian akan mengiringi mereka yang selalu ajeg di jalan Allah. Ajeg di jalan Allah berarti juga akan ajeg dalam kebaikankebaikan terhadap sesama manusia dan terhadap lingkungannya. ${ }^{43}$

Ketiga, Nasehat, yakni pandangan untuk saling mengingatkan dalam menuju aspek kebaikan, kebajikan dan kebenaran, serta menjauhkan diri dari keburukan, kejahatan dan kemungkaran, dalam hal manusia

${ }^{42}$ Wawancara dengan KH. Moh. Hasan Naufal (Gus Boy, Putra KH. Moh. Hasan Saifourridzall) di kantor pusat SMP Zainul Zainul Hasan Genggong pada tanggal 22Juli 2019.

${ }^{43}$ Wawancara dengan KH. dr. Abdul Haris Damanhuri (Gus Haris) di kantor pusat SMP Zainul Zainul Hasan Genggong pada tanggal 22 Agustus 2019. 
adalah sama derajat, harkat dan martabatnya, dan seorang santri harus mampu untuk saling menasehati dan berlomba lomba dalam hal kebajikan. mengsnI hal ini KH. Moh Hasan Saifourridzall mengutip firman Allah Surat Al-A'raf: 68 yang berbunyi "Dan aku pemberi nasebat yang terpercaya kepada kamu”. Dan sabda Rasulullah SAW. "Agama dalah nasehat". ${ }^{44}$ asehat-nasehat akan kebaikan yang selalu didasarkan tuntunan-tuntunan agama baik berkenaan dengan urusan duniawi maupun ukhrawi akan memberikan kebahagiaan dalam menjalani kehidupan di dunia ini dan setelahnya. Dalam hal ini nasehat-nasehat yang palinh sering disampaikan adalah terkait dengan keimanan kepada Allah SWT, hari akhir, malaikat, rasul-rasul Allah, adanya surga dan neraka dan agar senantiasa menjalankan perintah-perintah Allah SWT. baik yang berkaitan dengan ibadah maupun mu'amalah. Dengan memberi nasehat secara ikhlas dan senantiasa menjalankan apa dinasehatkan, terutama bagi diri sendiri dan keluarga khususnya, maka barulah akan menjadi pemberi nasehat yang terpercaya. ${ }^{45}$

Lebih lanjut dikatakan bahwa, saling nasehat menasehati dalam kebaikan dan taqwa adalah kewajiban bagi santri. Dan seyogyanya bagi santri agar senantiasa terlebih dahulu melaksanakan kebaikan-kebaikan dan menjauhkan diri dari segala keburukan, ketika dia memberikan nasehat tersebut. Jika demikian, maka nasehat yang diberikan akan didengarkan, mudah masuk dan mengena kepada orang yang dinasehati. Selain itu saling menasehati juga akan membuat santri senantiasa berlaku baik, menginggalkan yang buruk, dan saling introspeksi atas perilaku masingmasing. Dan ketika memberikan nasehat, sikap dan perilaku yang harus tetap dijunjung adalah kesopanan dan kesantunan. Nasehat menasehati dengan cara yang lembut, bijaksana dan menjauhkan diri dengan nasehat dengan cara-cara yang kasar apalagi merendahkan. ${ }^{46}$ Nasehat menasehati

${ }^{44}$ Lihat Surat Al-A'raf: 67 dan HR. Imam Turmudzi dari Tsauban AL-Bazzazy dari Ibnu Umar sebagaimana dikutip oleh Umar, Arief dkk. 1989. Pesantren Zainul Hasan Genggong Kraksaan, Sejarab Perjalanan dan Perkembangannya: 150 Tabun Menebar Ilmu di Jalan Allah. Probolinggo: TP. Hal. 261.

${ }^{45}$ Wawancara dengan KH. Asy'ari, santri KH. Moh. Hasan Saifouridzall yang juga seorang da'i dan pengasuh pondok pesantren Raudlatul Hasaniyah di Mojolegi Wangkal Probolinggo pada tanggal 29 Agustus 2019.

${ }^{46}$ Wawancara dengan Dr. Abd. Aziz, M.Ag. (santri KH. Moh. Hasan Saifouridzall), yang saat ini menjabat Ketua Umum Tanaszaha (Ikatan Alumni dan 
adalah tugas seorang muslim. Nasehat merupakan hadiah yang tak ternilai dalam hidup. Karena pada dasarnya manusia tidak akan pernah luput dari berbuat kesalahan. Dan nasehat menasehati adalah salah bentuk kasih sayang, kecintaan dan kepedulian yang lebih bermakna dan bermanfaat serta akan memberikan keberkahan dalam hidup.

Keempat, Taqwallah, salah satu sifat yang mengasumsikan bahwa dalam segala bentuk perilaku dan tindakan tiada yang lepas dari penglihatan Allah, oleh karenanya semua akan dimintai pertanggungjawaban. Oleh karenanya santri haruslah memahami bahwa dorongan untuk berbuat baik dan larangan berbuat mungkar haruslah berasal dari kesadaran bahwa Allah senantiasa mengetahui dan segala tindak laku akan dipertanggungjawabkan kepada Allah. Mengenai hal ini KH. Moh. Hasan Saifourridzall mengutip Firman Allah Surat Ali 'Imran: "Wahai orang-orang yang beriman! Bertqawalah kepada Allah sebenar-benar taqwa kepada-Nya". Dan sabda Rasulullah SAW. "Bertaqwalab kepada Allab dimanapun engkau berada". ${ }^{47}$

Bukti ketaqwaan kepada Allah adalah dengan berusaha sekuat tenaga untuk senantiasa menaati Allah dan tidak durhaka kepada-Nya, mengingat Allah dan tidak sekalipun melupakan-Nya, serta mensyukuri segala nikmat yang telah diberikan Allah dan tidak sekalipun dan sekecil apapun mengingkari-Nya sampai batas akhir kemampuan yang dimiliki dengan mengerahkan segala daya dan kemampuan. Dalam diri santri Pesantren Zainul Hasan Genggong, diajar dan ditanamkan untuk memelihara diri meyakini bahwa Allah SWT. senantiasa menyertai hamba, dan tidak sedetikpun hamba lepas dari pengawasan Allah SWT. Dengan penanaman bahwa segala kata, rasa, dan perilaku senantiasa disensor oleh Allah, santri akan senantiasa menjaga diri, menjauhkan diri dari berbuat hal-hal yang tidak sesuai dengan tuntunan agama. Selain itu motivasi dan pembiasaan dalam berbuat kebaikan juga senantiasa didengungkan dalam setiap kesempatan. Ketaqwaan akan mengantarkan seorang hamba untuk

Santri Pesantren Zainul Hasan) dan juga Rektor INZAH Kraksaan tanggal 16 Juli di Ruang Rektor.

${ }^{47}$ Lihat Surat Ali 'Imran: 102 dan HR. Imam Ahmad, Imam Turmudzi, Imam Hakim dan Imam Baihaqy, sebagaimana dikutip oleh Umar, Arief dkk. 1989. Pesantren Zainul Hasan Genggong Kraksaan, Sejarab Perjalanan dan Perkembangannya: 150 Tabun Menebar Ilmu di Jalan Allah.Probolinggo: TP. Hal. 263. 
memelihara diri menjauh dari siksaan Allah dengan menjalankan perintah dan menjauhi larangan-Nya. Dan dengan ketaqwaan yang tertanam, maka manusia akan mulia di sisi Allah SWT. Dalam diri orang yang bertaqwa akan terkumpul segala kebaikan, kebaikan ketika beribadah kepada Allah, kebaikan ketika bermu'amalah dengan sesama manusia, dan kebaikan ketika bermu'amalah dengan lingkungan serta memenuhi diri dengan sifat-sifat kebaikan. ${ }^{48}$

Jadi pada hakikatnya taqwallah merupakan tindakan seseorang untuk melindungi dirinya dari hukuman Allah dengan ketundukan total, menjaga diri dari kemusyrikan, dosa dari kejahatan-kejahatan dan hal-hal yang meragukan (syubhat) dan kesadaran bahwa dia tidak bisa berlepas diri dari penglihatan dan pengawasan Allah kapanpun, dimanapun, dan dalam keadaan bagaimanapun.

Kelima, Ridlallah, adalah mencari apa yang membuat Allah rela kepada hamba yang ditandai dengan tentramnya hatiyang disertai kepasrahan seoarang hamba. Tidak ada yang lebih berat bagi nafsu kecuali harus ridho terhadap ketentuan-Nya, karena ridho terhadap ketentuanNya biasanya berbeda dengan kerelaan hawa nafsu. Mengenai sikap ini KH. Moh. Hasan Saifourridzall mengutip firman Allah SWT. surat AlTaubah: 72 yang berbunyi "Dan keridlaan Allab lebib besar". Dan juga sabda Rasulullah SAW. "Tidak ada seorang muslim, manusia atau hamba ketika di waktu petang dan waktu pagi dia berkata: aku rela menerima Allah adalab tuban, Islam adalab agama, dan Mubammad adalab nabi, kecuali Allah memberikan hak hamba kelak di hari kiamat berupa ridha-Nya." 49

Ridhallah atau keridhaan Allah merupakan anugerah teragung yang ditberikan kepada hamba yang senantiasa mengikuti apa yang diinginkan oleh Allah. Keinginan tersebut pada dasarnya adalah untuk kebaikan hamba itu sendiri. Bila seorang hamba mengikuti apa yang diinginkan Allah, maka ia akan berbuat kebaikan, berhati lembut, tidak menyakiti sesama, menjaga keamanan dan kenyamanan sesamanya, mau membantu

${ }^{48}$ Wawancara dengan KH. Moh. Hasan Naufal di kantor SMP Zainul Zainul Hasan Genggong pada tanggal 21 Agustus 2019.

${ }^{49}$ Lihat Surat al-Taubah: 72 dan HR. Ibnu Majah dalam Kitab al-Zawaaid, sebagaimana dikutip oleh Umar, Arief dkk. Pesantren Zainul Hasan Genggong Kraksaan, Sejarah Perjalanan dan Perkembangannya: 150 Tabun Menebar Ilmu di Jalan Allah. Probolinggo: TP. Hal. 265. 
dan berkorban untuk sesamanya yang pada akhirnya adalah manifestasi dari ajaran Islam dalam perilaku hidup yang penuh dengan nilai rahmat bagi semesta. Ridha Allah bisa diketahui dengan, pertama,hal-hal yang disuka dan tidak disukai oleh Allah baik berupa ucapan ataupun perilaku dan tindakan. Kedua, hati kecil manusia yang paling dalam akan bicara bahwa hal itu diridhai atau tidak. Dan ketiga, tumbuhnya rasa yakin yang menghapus segala rasa gundah, galau, ragu, dan takut. ${ }^{50}$

Santri di Pesantren Zainul Hasan Genggong selalu diingatkan untuk senantiasa bersikap penuh kerelaan dalam menjalankan perintah-perintah Allah, kerelaan menjauhi larangan-larangan Allah, kerelaan kepada ketentuan dan pilihan Allah serta kerelaan terhadap apa yang diberikan dan dicegah oleh Allah. Kerelaan-kerelaan tersebut pada awalnya dimulai dengan adanya langkah yang agak memaksa khususnya bagi santri-santri yang masih baru, kemudian pembiasaan-pembiasaan, dan selanjutnya akan menimbulkan kesadaran-kesadaran untuk melakukan peraturan, kegiatan pesantren dan amaliah yang sesuai dengan ajaran-ajaran para pendahulu pondok pesntren sebagaimana yang diajarkan oleh Rasulullah. Selain itu keridhaan Allah tidak bisa dicapai begitu saja tanpa keridhaan orang tua dan guru. Ketika keridhaan orang tua, keridhaan guru didapat, maka kemudian akan menjadi keberkahan dalam hidup bagi santri. Jika keberkahan sudah didapat, maka keridhaan Allah akan menyertai. ${ }^{51}$

Keridhaan Allah SWT. merupakan tujuan akhir dari setiap muslim yang hanya dengannya seroang muslim mendapat anugerah yang sesungguhnya. Keridhaan itu diraih hanya dengan menjalankan semua hal yang diridhai Allah dan mencegah diri dari segala yang dilarang oleh Allah SWT. Oleh karenanya setiap muslim dituntut untuk memanifestasikan nilai-nilai keislaman dengan benar berdasarkan asas rahmat bagi semua.

Keenam, Ikhlas Lillahi Ta'ala, yakni memurnikan tujuan untuk mendekatkan diri kepada Allah dan menjauhkan diri dari pamrih kepada makhluk. Landasan ikhlas adalah memurnikan niat dan hanya karena

${ }^{50}$ Wawancara dengan KH. Ahmad Fauzi Imran, pengasuh PP. Islamiyah Syafi'iyah Kotaanyar yang merupakan santri KH. Moh. Hasan Saifourdzall pada tanggal 03 September 2019

${ }^{51}$ Wawancara dengan Dr. Abd. Aziz, M.Ag. (santri KH. Moh. Hasan Saifouridzall), yang saat ini menjabat Ketua Umum Tanaszaha (Ikatan Alumni dan Santri Pesantren Zainul Hasan) dan juga Rektor INZAH Kraksaan tanggal 16 Juli di Ruang Rektor. 
Allah semata. Mengani hal ini KH. Moh. Hasan Saifouridzall mengutip firman Allah SWT. Surah Al-Bayyinah: 5 "Dan mereka diperintah hanya untuk menyembah Allab semata-mata karena menjalankan agama. Dan maqalah dari KH. Moh. Hasan RA. "Bersibkan bersikan amal-amalmu dengan keikblasan, dan bersibkan keikblasanmu dengan laa haula wa laa quwwata illaa billah al-'aliyy al-'adbiim. ${ }^{52}$

Keikhlasan merupakan niat dan perbuatan baik dengan tanpa mengharapkan pamrih dari manusia dan hanya mengharapkan ridha Allah SWT semata. Ketika perbuatan baik dilakukan, maka apapun yang dilakukan yang datang dari manusia, baik berupa pujian ataupun cacian, tidak akan mempengaruhi perbuatan baik tersebut. Kebaikan akan terus dikerjakan dengan penuh kesadaran, berkesinambungan dan tanpa beban. Dalam diri santri Pesantren Zainul Hasan Genggong senantiasa diajarkan kesadaran bahwa apa yang ada dalam diri kita hanyalah titipan Allah semata, lalu berniat hanya karena Allah ketika melakukan segala sesuatu, dalam berbuat baik tidak boleh memilih-milih, dan melupakan setiap kebaikan yang sudah dikerjakan agar terhindar rasa angkuh dan sombong. ${ }^{53}$ Jadi ikhlas lilahi ta'ala adalah mengerjakan sesuatu dengan tanpa mengharapkan sesuatu yang lain dan hanya karena Allah SWT. Semua dimurnikan dan murni hanya karena Allah SWT. Dan hal ini akan tercermin dalam perilaku-perilaku terpuji baik ketika beribadah kepada Allah maupun ketika bermu'amalah dengan sesama dan lingkungan. Pengesaan kepada Allah dalam menjalankan kehidupan beragama, beribadah, berdo'a dan perbuatan taat lainnya dikerjakan semata-mata karena Allah.

Melalui nilai-nilai satlogi SANTRI tersebut, dinamika pendidikan Pesantren Zainul Hasan Genggong merupakan suatu yang dinamis dan inovatif dalam rangka mempertahankan sistem nilai dan sistem sosial

${ }^{52}$ Lihat Surat Al-Bayyinah: 5 dan maqalah KH. Moh. Hasan Genggong RA. sebagaimana dikutip oleh Umar,Arief dkk. 1989. Pesantren Zainul Hasan Genggong Kraksaan, Sejarah Perjalanan dan Perkembangannya: 150 Tabun Menebar Ilmu di Jalan Allah. Probolinggo: TP. Hal. 265.

${ }^{53}$ Wawancara dengan KH. Moh. Hassan Malik di kantor MA. Zainul Hasan 1 Komplek Gedung P5 Pesantren Zainul Hasan Genggong pada tanggal 11 Agustus 2019. Hal yang senada juga disampaikan oleh KH. Ahmad Fauzi Imran, pengasuh PP. Islamiyah Syafi'iyah Kotaanyar yang merupakan santri KH. Moh. Hasan Saifourdzall 
pesantren dengan tetap mengacu ke arah perkembangan yang lebih baik. Dan secara sosiologis, nilai-nilai satlogi SANTRI akan melahirkan perilaku dan tindakan yang efektif, yaitu potret santri dengan integritasyang mampu beramal saleh, berkomitmen, berdedikasi, memiliki kecakapan intelektual, emosional dan spirutual dalam mengarungi kehidupan di tengah-tengah masyarakat.

\section{Satlogi "SANTRI”; Local Genius Penguat Karakter}

Jika kita menelisik nilai-nilai yang ada dalam satlogi SANTRI, maka sebenarnya nilai-nilai Sopan Santun, Ajeg (Istiqamab), Nasehat, Taqwallah, Ridlallab, Ikblas Lillabi Ta'ala, adalah karakter yang harus dimiliki oleh santri di Pesantren Zainul Hasan Genggong. Jauh sebelum dicanangkan pendidikan budaya dan karakter bangsa pada tahun 2010, lalu diperkuat dengan penguatan pendidikan karakter pada tahun 2017, Satlogi SANTRI telah dicetuskan oleh KH. Moh. Hasan Saifourridzall dan menjadi nilainilai yang telah mengakar membudaya dalam pondok Pesantren Zainul Hasan Genggong sejak tahun 1989.

Satlogi SANTRI, yang merupakan nilai-nilai kearifan lokal (local genius) Pesantren Zainul Hasan Genggong, telah ditanamkan kepada para santri yang meliputi komponen pengetahuan, kesadaran dan tindakan untuk melaksanakan nilai-nilai tersebut baik terhadap Tuhan Yang Maha Esa, diri sendiri, sesama, lingkungan, maupun dalam kehidupan berbangsa dan bernegara. Dan jika dilihat, maka sebenarnya nilai-nilai Satlogi SANTRI (Taqwallah, Ridlallah, Ikblas Lillahi Ta'ala)ini berpijak pada landasan ideologis Pancasila sebagai falsafah hidup bagi bangsa Indonesia, yang menempatkan Ketuhanan Yang Maha Esa sebagai sila pertama yang harus melandasi dan menjiwai seluruh sila-sila lainnya. Hal ini mencerminkan karakter religius yang harus dimiliki oleh santri Pesantren Zainul Hasan Genggong.Nilai karakter religius mencerminkan keberimanan terhadap Tuhan yang Maha Esa yang diwujudkan dalam perilaku melaksanakan ajaran agama dan kepercayaan yang dianut, menghargai perbedaan agama, menjunjung tinggi sikap toleran terhadap pelaksanaan ibadah agama dan kepercayaan lain, hidup rukun dan damai dengan pemeluk agama lain. Nilai karakter religius, meliputi tiga dimensi relasi sekaligus, yaitu hubungan individu dengan Tuhan, individu dengan 
sesama, dan individu dengan alam semesta (lingkungan). Nilai karakter religius ini ditunjukkan dalam perilaku mencintai dan menjaga keutuhan ciptaan.

Selanjutnya karakter nasionalis juga menjadi bagian karakter yang tidak terpisahkan dalam nilai-nilai Santlogi SANTRI yang tergambar dalam nilai Sopan Santun. Nilai karakter nasionalis merupakan cara berpikir, bersikap, dan berbuat yang menunjukkan kesetiaan, kepedulian, dan penghargaan yang tinggi terhadap bahasa, lingkungan fisik, sosial, budaya, ekonomi, dan politik bangsa, menempatkan kepentingan bangsa dan negara di atas kepentingan diri dan kelompoknya. Dalam nilai Sopan Santun juga tercermin karakter gotong royong yang mencerminkan tindakan menghargai semangat kerja sama dan bahu membahu menyelesaikan persoalan bersama, menjalin komunikasi dan persahabatan, memberi bantuan/pertolongan pada orang-orang yang membutuhkan.

Sedangkan dalam nilai Ajeg/Istiqamah terkandung karakter mandiri, merupakan sikap dan perilaku tidak bergantung pada orang lain dan mempergunakan segala tenaga, pikiran, waktu untuk merealisasikan harapan, mimpi dan cita-cita. Disamping itu dalam nilai Ajeg/Istiqamah juga terkandung karakter integritas. Karakter integritas merupakan nilai yang mendasari perilaku yang didasarkan pada upaya menjadikan dirinya sebagai orang yang selalu dapat dipercaya dalam perkataan, tindakan, dan pekerjaan, memiliki komitmen dan kesetiaan pada nilai-nilai kemanusiaan dan moral.

Nilai-nilai Satlogi SANTRI dan karakter-karakter tersebut di atas, bukanlah nilai yang berdiri dan berkembang sendiri-sendiri, akan tetapi antara satu nilai dan karakter dengan nilai dan karakter lainnya saling beriteraksi, yang berkembang secara dinamis membentuk keutuhan pribadi. Nilai-nilai Satlogi SANTRI merupakan kearifan lokal (local genius) Pesantren Zainul Hasan Genggong sebagai salah satu upaya terbaik dalam mempertahankan prinsip-prinsip moral, kecakapan spiritual, kecakapan interpersonal dan emosional yang memungkinkan santri berinteraksi secara efektif dalam berbagai keadaan serta komitmen untuk berkontribusi dengan komunitas dan masyarakatnya. 


\section{KESIMPULAN}

Sebagaimana pesantren pada umumnya, Pesantren Zainul Hasan Genggong merupakan pesantren yang arus utama pembentukan karakter santrinya adalah berwawasan keislaman, keimanan dan ketaqwaan kepada Allah SWT. Dan wawasan-wawasan tersebut merupakan landasan yang kuat dalam terbentuknya karakter-karakter yang lain yang meliputi karakter terhadap diri sendiri, sesama, lingkungan dan kebangsaan yang terbentuk melalui olah pikir, olah hati, olah raga dan olah rasa serta karsa yang pada akhirnya akan membentuk karakter-karakter manusia yang utuh (paripurna).

Nilai-nilai Satlogi SANTRI (Sopan Santun, Ajeg (Istiqamah), Nasebat, Taqwallah, Ridlallah, Ikblas Lillabi Ta'ala) yaang ada diPesantren Zainul Hasan Genggong merupakan nilai-nilai kearifan lokal (local genius) yang dicetuskan oleh KH. Moh. Hasan Saifouridzall dalam mempertahankan prinsip-prinsip moral, kecakapan spiritual, kecakapan interpersonal dan emosional yang sesuai dan memperkuat nilai-nilai karakter religius, nasionalis, mandiri, gotong royong dan inetgritas. Apabila penanaman nilai-nilai Satlogi SANTRI berjalan baik, maka pembangunan karakter bangsa khususnya bagi santri-santri di pesantren Zainul Ahasan Genggong akan terwujud. 


\section{Daftar Pustaka}

Asrohah, Hanun. 2004. Pelembagaan Pesantren Asal usul dan Perkembangan Pesantren Di Jawa. Jakarta: Bagian Proyek Peningkatan Informasi Penelitian dan Diklat Keagamaan.

Ayatrohaedi. 1986. Kepribadian Budaya Bangsa (Local Genius). Jakarta: Pustaka Pelajar.

Aziz, Abd. 2013. Filsafat Pesantren Genggong. Probolinggo: STAI Zainul Hasan Genggong.

Bisri, Mustofa. 2007. "Pesantren dan Pendidikan", Tebuireng, Edisi 1/Tahun I/Juli-September 2007.

Bogdan, R.C dan Biklen, S.K. 1992. Qualitative Research For Education: An Introduction to Theory and Methods. Bostob: Allyn and Bacon.

Departemen Agama RI. 2003. Pola Pembelajaran di Pesantren, Jakarta: Departemen Agama . 2004. Profil Pondok Pesantren Mu'adalah. Jakarta: Departemen Agama RI. Agama RI. .2012. Al-Quran dan Terjemahnya. Jakarta: Departemen

Kemendiknas. 2010. Kerangka Acuan Pendidikan Karakter. Jakarta: Dirjen PT.

Kemendiknas. 2010. Desain Induk Pendidikan Karakter. Jakarta: Dirjen Pendas.

. 2010. Desain Induk Pendidikan Karakter. Jakarta: Dirjen Pendas.

. 2011. Bahan Pelatihan Pengembangan Pendidikan Budaya dan Karakter Bangsa. Jakarta: Dirjen Pendas.

Khozin. 2006. Jejak-Jejak Pendidikan Islam di Indonesia: Rekonstruksi Sejarah Untuk Aksi. Malang: UMM Press.

Koesoema, Doni. 2010. Pendidikan Karakter: Strategi Mendidik Anak Di Zaman Global. Jakarta: Grasindo. 
Kusnadi. 2001. "Masyarakat "Tapal Kuda": Konstruksi Kebudayaan dan Kekerasan Politik", dalam Jurnal Ilmu-ilmu Humaniora, Vol.III, No.2 Madjid, Nurcholish. 1994. Bilik-bilik Pesantren; Sebuah Potret Perjalanan. Jakarta: Paramadina..

Mas'ud, Abdurrahman. 2007. Memahami Agama Damai Dunia Pesantren, dalam Badrus Sholeh (ed.). Budaya Damai Komunitas Pesantren. Jakarta: LP3ES.

Miles, M. Dan Huberman, A.M. 2007. Analisis Data Kualitatif. Jakarta; UI Press.

Mun'im, A. Rafiq Zainul. 2009. "Peran Pesantren dalam Education For All di Era Globalisasi”, http://ejournal.sunan-ampel.ac.id/index.php/JPI/ article/view/177/ 162 diakses Tanggal 24 Mei 2018.

Poerwadarmintha, WJS. 2006. Kamus Besar Bahasa Indonesia. Jakarta: Balai Pustaka.

PPRI Nomor 55 Tahun 2007 Tentang Pendidikan Agama dan Pendidikan Keagamaan.

Soewadji, Yusuf. 2012. Pengantar Metodologi Penelitian.Jakarta: Mitra Wacana Media.

Syam, Nur. 2012. Mazhab-Mazhab Antropologi. Yogyakarta: LkiS.

Tim PPK Kemendikbud. 2017. Modul Pelatihan Penguatan Pendidikan Karakter. Jakarta: Kemendikbud RI

Tim Penyusun Kamus Bahasa Indonesia. 2008. Kamus Bahasa Indonesia. Jakarta: Pusat Bahasa Depdiknas.

Tim PPK Kemendikbud. 2017. Penguatan Pendidikan Karakter. Jakarta: Kemendikbud.

Wahid, Abdurrahman.2010. Menggerakkan Tradisi.Yogyakarta: LkiS.

Zubaedi. 2011. Desain Pendidikan Karakter: Konsepsi dan Aplikasinya dalam Lembaga Pendidikan. Jakarta: Kencana.

Umar, Arief dkk. 1989. Pesantren Zainul Hasan Genggong Kraksaan, Sejarah Perjalanan dan Perkembangannya: 150 Tahun Menebar Ilmu di Jalan Allah. Probolinggo: TP.

UU RI Nomor 20 Tahun 2003 Tentang Sistem Pendidikan Nasional. 